\title{
Amnesic effects of ether and electroconvulsive shock in mice'
}

MICHAEL J. HERZ, HARMAN V. S. PEEKE AND EVERETT J. WYERS

Mice were given a painful foot-shock upon stepping through a small hole into a dark chamber. Different groups were administered either ECS or $40 \mathrm{sec}$. or $70 \mathrm{sec}$. of ether following the learning trial. On a test trial $22 \mathrm{hr}$. later the $70 \mathrm{sec}$. etherization and ECS groups showed no memory for the footshock while the shocked but untreated control Ss evidenced good retention. The results support a consolidation disruption interpretation of retrograde amnesia.

Several investigations (Abt, Essman, \& Jarvik, 1961; Essman \& Jarvik, 1961; Pearlman, Sharpless, \& Jarvik, 1961) have indicated that ether anesthesia, induced shortly after a single shock-avoidance trial interferes with the memory for the experience. However, one of the present authors (Herz, 1962) failed to find retrograde amnesia utilizing the procedure and the duration of anesthesia used by Abt, Essman, \& Jarvik (1961). However, amnesic effects were suggested by the results of a group etherized for a longer period of time.

The present investigation was undertaken to assess the importance of anesthesia duration in the production of retrograde amnesia and to directly compare ether-and electroconvulsive shock-produced retrograde amnesia. Method

The Ss were 75 male and female Swiss-Webster mice obtained from the colony maintained at U.S.C. They were approximately 6 weeks of age and all were naive.

A "step-through" avoidance learning apparatus (Essman \& Alpern, 1964) was used in the study. It consisted of a $6-1 / 4 \mathrm{~cm} \times 2-1 / 4 \mathrm{~cm}$ metal platform extending horizontally from the lower edge of a 3-1/4 $\mathrm{cm}$ diameter hole. The hole served as the entrance to a darkened chamber, the metal floor of which was $5 \mathrm{~mm}$ below the level of the platform. A $60 \mathrm{w}$ bulb in a reflector $30 \mathrm{~cm}$ above the platform was illuminated during the experimental sessions. The apparatus was placed at the edge of a laboratory table so that the distance between the platform and the floor of the room was approximately one meter. The room temperature was $30-31^{\circ} \mathrm{C}$.

Ss were assigned to seven groups of nine each (additional Ss were utilized to replace those that failed to recover from ECS or ether): (1) a shock control group (S) which received foot-shock on stepping from platform to chamber on Day 1 and received no further treatment, (2) a group which received foot-shock and was then immediately etherized for $40 \mathrm{sec},\left(\mathrm{SE}_{40}\right),(3)$ a group treated as group $\left(\mathrm{SE}_{40}\right)$ but etherized for $70 \mathrm{sec} .\left(\mathrm{SE}_{70}\right)$, (4) a group receiving foot-shock followed immediately by ECS (SECS), (5) a group receiving no foot-shock on stepping through the hole (N), (6) a group receiving $70 \mathrm{sec}$. of ether following a non-shocked stepthrough $\left(\mathrm{NE}_{70}\right)$, and (7) another non-shocked group administered ECS immediately following a step-through (NECS).

Ss were caged according to groups and had free access to food and water. On the first experimental day each $S$ was lifted by the tail and placed on the platform with the head facing the hole. The latency from platform placement to placement of one paw on the chamber floor was recorded. Ss with initial step-through latencies greater than $10 \mathrm{sec}$. were discarded and replaced with new Ss (one $S$ in group SECS and one in group N). Ss in groups $\mathrm{S}, \mathrm{SE}_{40}, \mathrm{SE}_{70}$, and $\mathrm{SECS}$ received a $3 \mathrm{ma}$ foot-shock (from a constant current source) when one foot made contact with the chamber floor, thus completing a circuit between the platform and the chamber floor. Ss in the remaining groups received no foot-shock.

Ss in the ether groups, $\mathrm{SE}_{40}, \mathrm{SE}_{70}$, and $\mathrm{NE}_{70}$, were removed from the chamber after stepping through and immediately placed in a $1000 \mathrm{cc}$ container which contained gauze pads saturated with ether. Additional ether was added between animals so that the gauze remained saturated. With this procedure Ss lost the righting reflex within 20-30 sec. Ss were kept in the container for either 40 or 70 sec., depending upon the group to which they were assigned. (Six Ss failed to recover from 70 sec. of ether.)

Ear clip electrodes (with electrode paste) were attached to the animals in the ECS groups immediately following their removal from the chamber. ECS was induced by passing $120 \mathrm{v}$ (r.m.s.), 60 cycle sine wave, 15-18 ma, through the animal for $200 \mathrm{msec}$. Tonicclonic convulsions were produced in all Ss. (Four animals failed to recover from ECS treatment.) The median delay from foot-shock to application of ECS was $10 \mathrm{sec}$.

Twenty-two hours after the first experimental session all Ss were again placed on the platform and the stepthrough latency recorded. Animals that remained on the platform for more than $30 \mathrm{sec}$. without stepping through the hole were removed and assigned a latency of $30 \mathrm{sec}$. for the trial. None of the Ss received footshock on the test trial day.

\section{Results}

Median step-through latencies for Day 1 and Day 2 are presented for all groups in Fig. 1. Overall analyses of variance (Kruskal-Wallis) indicated no significant differences among groups for Day 1 and significant differences among groups $(\mathrm{H}=24.79, \mathrm{p}<.001)$ for Day 1 -Day 2 


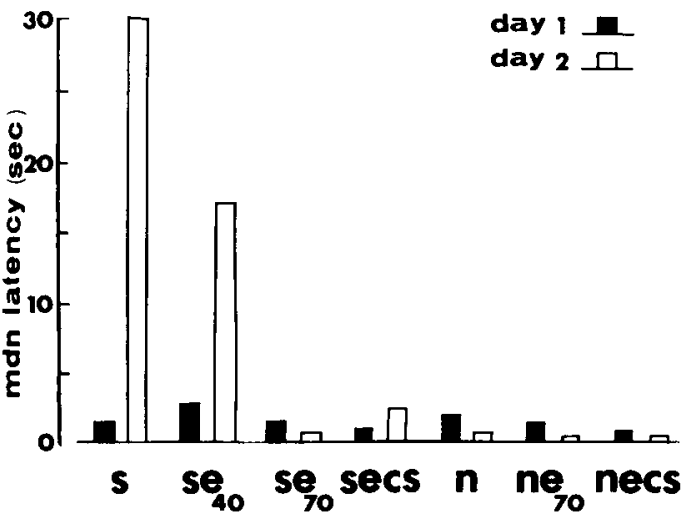

Fig. 1. Median Day 1 and Day 2 ste p-through latencies (in sec.) for shock control group (s), shocked 40 sec. ether group $\left(\mathrm{se}_{40}\right)$, shocked $70 \mathrm{sec}$. ether group ( $\mathrm{se}_{70}$ ), shocked ECS group (secs), non-shocked control group $(\mathrm{n})$, non-shocked 70 sec. ether group (ne ${ }_{\mathbf{7 0}}$ ), and non-shocked ECS group (necs).

difference scores. There was no significant difference among groups $\mathrm{SE}_{70}, \mathrm{SECS}, \mathrm{N}, \mathrm{NE}_{70}$, and NECS for Day 2 latencies. Mann-Whitney U tests performed between the shock control group (S) and the above 5 groups combined, and between group $\mathrm{SE}_{40}$ and the above 5 groups both yielded values significant beyond the .001 level. MannWhitney comparison of groups $S$ and $\mathrm{SE}_{40}$ resulted in $\mathrm{H}=24(\mathrm{p}<.10) .2$

\section{Discussion}

The results clearly indicate that the foot-shock was sufficient to produce one-trial avoidance learning in the shock control animals (S). Approximately $60 \%$ of the animals in that group remained on the platform for the full $30 \mathrm{sec}$. In addition, both ECS and $70 \mathrm{sec}$. ether produced clear retrograde amnesia as evidenced by the absence of a difference between these two groups and the non-shocked control groups. Further support for an amnesic interpretation of these results is offered by the finding that nearly $60 \%$ of the shock-70 sec. ether Ss and $70 \%$ of the shock-ECS animals had unchanged or decreased latencies on the Day 2 test trial whereas all of the Ss in the shock control group showed increased latencies on this trial. The equivocal results with the shock-40 sec. ether group supports the contention that duration of etherization is one of the important variables in ether-produced amnesia. Although $70 \mathrm{sec}$. of anesthesia is sufficient to induce an amnesic effect, $40 \mathrm{sec}$. is not. The comparison between the $70 \mathrm{sec}$. ether and ECS experimental groups suggests that the two methods have a similar effect on the memory for the foot-shock.

These results, when considered in conjunction with the findings of Herz (1962) and Alpern \& Kimble (in press) suggest that ether-produced amnesia is determined, to some degree, by the interaction of temperature and duration of anesthesia. Jarvik (1964) has also found temperature to be a critical variable in the production of ether amnesia. Herz (1962) found that $120 \mathrm{sec}$. of etherization gave results suggestive of amnesia at $22^{\circ} \mathrm{C}$, while Alpern \& Kimble (in press) found that $15 \mathrm{sec}$. of ether was sufficient to produce clear amnesic effects with potentiated ether (the etherization chamber was heated to $38^{\circ} \mathrm{C}$ ). The present study indicated that clear retrograde amnesia can be produced with intermediate temperature $\left(31^{\circ} \mathrm{C}\right)$ and duration $(70 \mathrm{sec}$.$) .$

The results of the present investigation indicate that both ether and ECS, when administered immediately following a painful foot-shock, produce relatively complete retrograde amnesia for that event. Although alternative explanations for the retrograde amnesic effect have been offered (e.g., the conditioned inhibition hypothesis of Lewis \& Maher, 1965) the present results appear to support a consolidation theory interpretation since both amnesic agents were administered outside of the experimental situation. The resulting conditioned inhibition or relaxation, if any, would therefore be conditioned to the place of treatment rather than to the experimental apparatus, a point raised in a recent reply to Lewis \& Maher (1965) by McGaugh \& Petrinovich (in press).

\section{References}

Abt, J. P., Essman, W. B., \& Jarvik, M. E. Ether-induced retrograde amnesia for one-trial conditioning in mice. Science, 1961 , 133, 1477-1478.

Alpern, H. P., \& Kimble, D. P. The retrograde amnesic effects of diethyl ether and Bis (trifluoroethyl) ether. J. comp. physiol. Psychol., in press.

Essman, W. B., \& Alpem, H. P. Single trial conditioning: Methodology and results with mice. Psychol. Rep., 1964, 14, 731-740.

Essman, W. B., \& Jarvik, M. E. Impairment of retention for a conditioned response by ether anesthesia in mice. Psychopharmacalogia, 1961, 2, 172-176.

Herz, M. J. The effects of ether on the retention of a one-trial avoidance response. Unpublished M. A. thesis. San Francisco State College, 1962.

Jarvik, M. E. The influence of drugs on memory. In H. Steinberg, A. V. S. DeReuck, \& J. Knight (Eds.), Animal behaviour and drug action. Boston; Little-Brown, 1964.

Lewis, D. J., \& Maher, B. A. Neural consolidation and electroconvulsive shock. Psychol. Rev., 1965, 72, 225-239.

McGaugh, J. L., \& Petrinovich, L. F. Neural consolidation and electroconvulsive shock reexamined. Psychol. Rev., in press.

Pearlman, C., Sharpless, S. K., \& Jarvik, M. E. Retrograde amnesia produced by anesthetic and convulsive agents. J. comp. physiol. Psychol., 1961, 54, 109-112.

\section{Notes}

1. This study was supported in part by Research Grants G-18891 and GB-4363 (to E. J. Wyers) from the National Science Foundation and by Public Health Service Fellowship 5 F1-MH-22,269 (to M. J. Herz) from the National Institute of Mental Health.

2. A replication of this study was carried out with an additional 63 mice obtained from a commercial supplier. These animals were older males (12 weeks) and were much more active and very difficult to handle. With the exception of the $40 \mathrm{sec}$. ether group, which in the replication did not differ from the shocked 70 sec. ether and ECS groups, the same pattern of results and significant differences emerged. It should aiso be noted that the Day 1 and Day 2 latencies were significantly shorter than in the reported study. 